\title{
Cryptosporidium and Giardia lamblia Epidemiology in Middle Eastern Countries: study of the proliferation problem in the aquatic environment
}

\author{
Nadeem A Khan ${ }^{1}$, Rachida El Morabet ${ }^{2}$, Roohul Abad Khan ${ }^{3, *}$, Soufiane Bouhafa ${ }^{2}$, \\ Larbi Barhazi ${ }^{2}$, Vitaliy Sobyna ${ }^{4}$, Dmytro Taraduda $^{4}$, Igor Neklonskyi ${ }^{4}$ \\ ${ }^{1}$ Civil Engineering Department, Jamia Millia Islamia, New Delhi, India \\ ${ }^{2}$ Department of Geography, LADES Lab, FLSH-M, Hassan II University of Casablanca, \\ Mohammedia, Morocco \\ ${ }^{3}$ Department of Civil Engineering, King Khalid University, Abha, Saudi Arabia \\ ${ }^{4}$ Department of Logistics and Technical Support of Rescue Operations, National University of Civil Defence \\ of Ukraine, Kharkiv, Ukraine \\ *corresponding author e-mail: rakhan@kku.edu.sa
}

Received: 6 March 2021 / Accepted: 2 April 2021

\begin{abstract}
The aim is to present a summarized study of the available literature on Cryptosporidium and Giardia lamblia for Middle Eastern countries, in order to identify trends in human cryptosporidiosis and childhood morbidity, and to raise awareness among residents. This is necessary in order to address the gap in preventive measures required to mitigate the overall effect attributed to associated illness and its impact in the already water stressed Middle Eastern countries. To assess seroprevalence of Cryptosporidium and Giardia lamblia in Middle Eastern countries systematic review was carried out based on online articles published from 2010-2018. PubMed, Web of Science, Google Scholar, Science Direct, Scopus, World Bank and WHO report and scientific database were explored. The current study highlights the existing subsequent epidemiology, its seroprevalence distribution, genetic diversity across Middle Eastern countries since 2009. This study therefore will provide the platform for future research work and development in comprehending Cryptosporidium and Giardia lamblia epidemiology in Middle Eastern countries. It was found that lack of awareness, personal hygiene and sanitation facilities, poverty, indiscriminate eating habits are favourable infestation conditions for Cryptosporidium and Giardia lamblia infections. The prevalence for both Cryptosporidium and Giardia lamblia, is higher in developing countries as compared to developed countries. The originality is that it is the only study of its kind in the region, as such studies are still lacking in Middle East countries as compared to other European, Asian, American continents and countries.
\end{abstract}

Keywords: water resources, tap water contamination, epidemiology, hygiene and sanitation, protozoan parasites, seroprevalence, childhood morbidity.

\section{Introduction}

Water resources (surface and underground fresh water) must support the vital activity of humans, plants and animals on the planet. However, due to the negative technogenic influence (Ziarati et al., 2021; Khan et al., 2019a; Khan et al., 2019b; Deineka et al., 2018), as well as due to climatic factors (Dang et al., 2018; Liu et al., 2017), in some countries there are problems with the provision of water supply, safe for consumption. 
There are many literatures on protozoan parasites around the world published in peer reviewed journal. However, literature from Middle Eastern countries is still lacking even though it is among one of the most water stressed region in the world. The pathogen entry to water resources is mainly attributed to improper water facilities, insufficient water purification processes and in water scarce region like Middle East water contamination and entry of protozoan parasites like Cryptosporidium and Giardia lamblia highly is highly susceptible (Mazzoni \& Zaccagni, 2019). This review has covered available literature on Cryptosporidium and Giardia lamblia for Middle Eastern countries. This summarized study will be one of its kind in the region as such studies are still lacking in Middle Eastern countries as compared to other European, Asian, American continents and countries (Xu \& May, 2017; Michel et al., 2012; Terink et al., 2013). Figure 1 presents the map of Middle Eastern countries covered in this study.

The second primary cause of death among children less than five years is diarrhoea. Each year about 525,000 deaths among kids are attributed to diarrhoea. Globally there are about 1.7 billion cases of diarrhoea each year (WHO, 2019; U.S.H.O.F., 2016). In children below five years mortality (no. of deaths) for the year 2016 in Middle
Eastern countries was 1936 (Iraq), 870 (Iran), 117 (Jordan), 1 (Kuwait), 17 (Lebanon), 10 (Oman), 1 (Qatar), 87 (Saudi Arabia), 1519 (Syria), 5 (United Arab Emirates) and 3702 (Yemen) (WHO, 2019; U.S.H.O.F., 2016). Cryptosporidium is reported secondary cause of diarrhoea only behind rotavirus. The leading parasitic protozoa causing waterborne enteric disease outbreaks at global level are Cryptosporidium and Giardia lamblia (Efstratiou et al., 2017). Originating from faeces of infected hosts they can be transmitted to new hosts via oral-faecal route upon contact with contaminated soil, water, feed and food. Hence, the study has focused on each of this water borne protozoa.

\section{Materials and Methods}

In order to assess seroprevalence of Cryptosporidium and Giardia lamblia in Middle Eastern countries systematic review was carried out based on online articles published from 2010-2018. PubMed, Web of science, Google Scholar, Science Direct, Scopus, World Bank and WHO report and scientific database were explored to retrieve necessary information for assessment. The present review was performed using keywords, Cryptosporidium, Cryptosporidiosis, Giardia lamblia

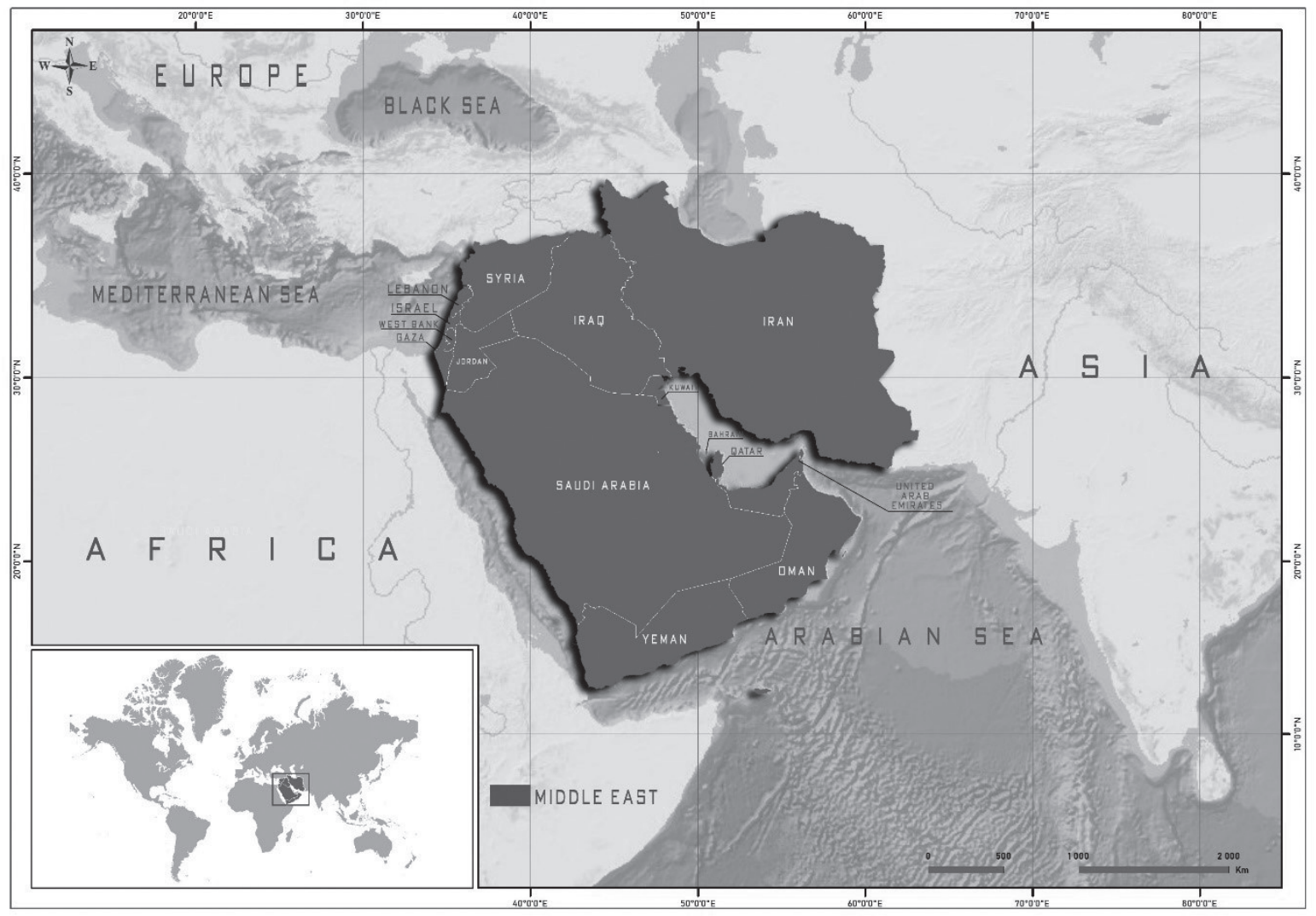

Figure 1. Map of Middle Eastern countries covered in this study 
combined or as individual country for Middle Eastern countries. The literature distribution of Cryptosporidium and Giardia lamblia is presented in Figures 2 and 3.

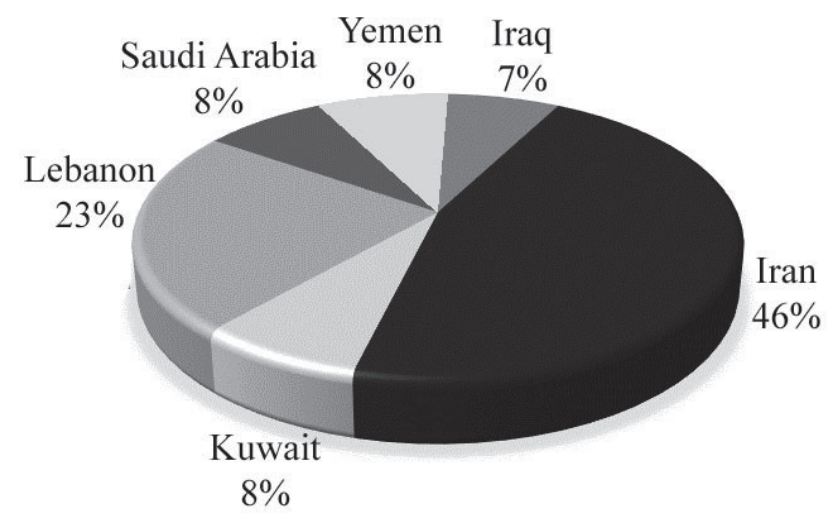

Figure 2. Cryptosporidium literature distribution in Middle Eastern countries

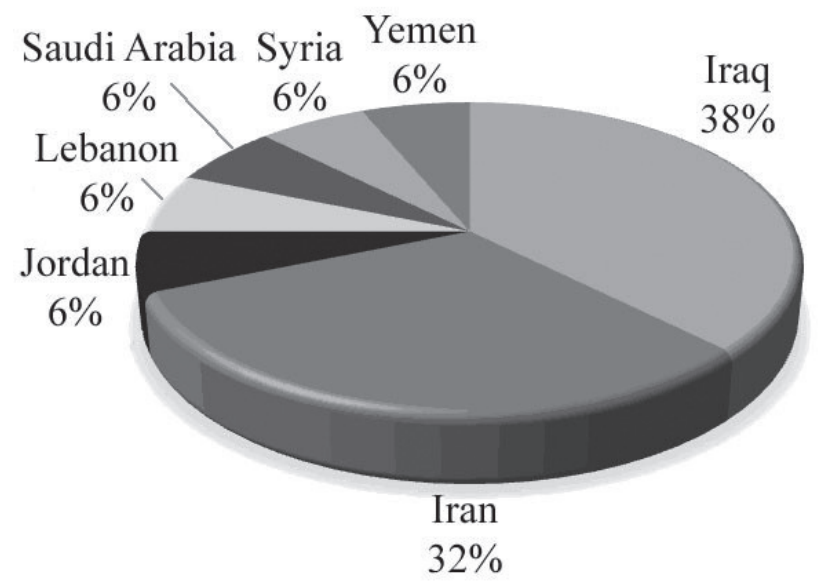

Figure 3. Giardia lamblia literature distribution in Middle Eastern countries

\section{Results and Discussion}

This study covered articles and reports published for Middle Eastern countries covering Cryptosporidium and Giardia lamblia. These studies were conducted based on host (Human (Infants, Children, Women, Elderly) or animals (bird, camel, sheep) for the identified Cryptosporidium and Giardia lamblia.

\subsection{Cryptosporidium Seroprevalence in Middle East}

The data obtained from literature was summarized and represented in Table 1. Majority of the studies infers that C. hominis and C. parvum are the primary Cryptosporidium species responsible for causing infection in Human population. In study from Kuwait, C. parvum was the dominant species present with its subtype prevailing in order of IIa, IId and IIc, while C. hominis followed with its subtype in prevailing order of Id, Ia and Ie, inferring that genetic of parasite may play a major role in human cryptosporidiosis (Iqbal et al., 2011). Other species studies did not identify genetics or sub species of Cryptosporidium species. This is primarily being due to non-uniform testing procedure and standards adopted across Middle Eastern countries along with lack of standardized infrastructure. PCR (Polymerase Chain Reaction) yielded highest rate of detection as compared to ELISA (Enzyme-linked immunosorbent assay) and MZN (modified ziehl neelsen) staining method. From three techniques; Direct Fluorescent Antibody (DFA), modified acid fast stain and Immune Card techniques used to detect C. parvum, modified acid fast stain performed better (Ali et al., 2014). Again, results of studies have variation depending upon the method used to identify genotype of Cryptosporidium.

In study from Kuwait; children in 4-8 years of age group are mostly affected (Iqbal et al., 2011). Iran reported, Cryptosporidium prevalence of $9.7 \%$ was higher in children under 4-5 years of age with C. parvum prevailing in diarrheic children (Mahdavi Poor et al., 2015; Dabirzadeh et al., 2017). Even the study in 2011 reported similar results of C. parvum dominance over other species of Cryptosporidium (Taghipour et al., 2011). Lebanon reported prevalence rate of children was $10.4 \%$, and was peaking in children under five years of age with 11\% (Osman et al., 2017; Osman et al., 2018; Osman et al., 2015). In Iraq; or children also Acid fast (AF) staining technique provided better results than immune cards (Ali et al., 2014).

The Cryptosporidiosis in Out patients, Hospitalized patients, immune suppressed patients are attributed to $C$. hominis and C. parvum. In Iran; among gastroenteritis patient, Cryptosporidium was reported for only 2.3\% (Gholami et al., 2014). In Lebanon the reported prevalence rate was $21 \%$ in adenocarcinoma patients, $11 \%$ in symptomatic patients (Osman et al., 2017; Osman et al., 2018; Osman et al., 2015). Cryptosporidium was reported not to cause any effect on gastroenteritis but children under 10 year reported highest infection percent (Ghenghesh et al., 2016). Lack of data on age group in studies made it difficult to attribute any Cryptosporidium subspecies to specific age group. However, in displaced population (refugees) C. parvum was reported to be the cause of Cryptosporidiosis.

Among adult birds wild and domestic C. meleagridis, (IIIgA22G3R1) and C. baileyi (IIIgA23G2R1) were identified as cryptosporidiosis causing protozoa. While C. bovis, C. ryanae and C.parvum were identified as cause of cryptosporidiosis in Juvenile calves. C. parvum has been identified as causing infection in humans which was also detected in calves 
which can be responsible for zoonotic transmission of cryptosporidiosis.

\subsection{Giardia lamblia seroprevalence in Middle East}

Giardia duodenalis (G. intestinalis and G. lamblia) are morphologically similar terms which are used interchangeably in this study. From Giardia lamblia species only G. duodenalis can cause infection among humans. Majority of the reports have identified $G$. duodenalis as cause of Diarrhoea in hosts. However, among the reported prevalence of Giardia lamblia subspecies Assemblage/Genotype A. and Assemblage $B$. among various segment of population and age groups. Other subspecies Assemblage E. and Assemblage F. are sparsely reported.

Giardia lamblia infections in Saudi Arabia were reported to be prevalent more in children under five years old (Shalaby et al., 2011). In Iran, prevalence of Giardia lambliasis among children reported highest in children 4-6 years and lowest for children 0-2 years (Faraji et al., 2015). Also, in other study for diarrheic children; found Assemblage B., B-IV and B-III predominant prevalence over Assemblage A. (El-Badry et al., 2018). Assemblage B. prevailed over Assemblage A. G. lamblia was prevalent in 1-10 years of age group in Iraq (Salman et al., 2015). The study in Lebanon reported, genotype Assemblage B. was predominant over Assemblage A. among school children (Osman et al., 2016). This may be due to Children infected with Assemblage B. released more cysts as compared to children infected with Assemblage A. (El Fatni et al., 2014).

The studies covering adult patients in Iraq, reported predominance of Assemblage A. over Assemblage B. Also study among food handlers depicted similar trend (Turki et al., 2015). The prevalence rate was affected by seasonal variation and was reported to be $25 \%$ for summer, $20 \%$ for spring, $15.15 \%$ for autumn and $0 \%$ in winter (Taha et al., 2018). Based on gender the prevalence in boys was higher than in girls (El Fatni et al., 2014). Giardia lambliasis infections are more prevalent more in children under five years old and in elder population (Shalaby et al., 2011). Human transmission was indicated but the need for more investigations has been suggested to determine the dynamics of the real transmission and epidemiology (Hijjawi et al., 2015). Adaptation of clean and hygienic practices was identifies as means to control transmission and morbidity attributed to G. duodenalis (AlMekhlafi, 2017).

\subsection{Discussion regarding the transmission of Cryptosporidium and Giardia lamblia in Middle Eastern countries}

A significant relation for based on gender, socio- economy in rural areas and animal contact role was derived (Shalaby \& Shalaby, 2015). High affinity of infections was associated with tap water contamination and animal contact in urban populations (Gawad et al., 2018). There is a potential risk of zoonotic transmission of Cryptosporidium and Giardia lamblia to human beings (Ghoneim et al., 2017). Based on the zoonotic patterns of isolates, it can be identified that the mode of transmission is direct or indirect animal contact (Taghipour et al., 2011). Lebanon reported molecular analysis as an important tool to identify mode of transmission (Osman et al., 2016). Kuwait reported genetic condition of parasites plays important role in human cryptosporidiosis (Iqbal et al., 2011). Report from Jordan identified human to human transmission (Hijjawi et al., 2015). When there is no significant demographic variation then modes of transmission can be ingestion of contaminated water, and human or animal contacts (Iqbal et al., 2001). Identification of the transmission routes will help in adopting mitigation measures. Hence, prevent spread of the infection is the most effective strategy (Abd El Kader et al., 2012). However, zoonotic transmission cannot be eradicated from Middle Eastern countries as whole region practices animal husbandry owing to extreme conditions prevailing in most of the region rendering animals as sustainable source of food and other products thereof. Lack of awareness, personal hygiene and sanitation facilities, poverty, indiscriminate eating habits are favourable infestation conditions for Cryptosporidium and Giardia lamblia infections. The prevalence for both Cryptosporidium and Giardia lamblia, is higher in developing countries as compared to developed countries (Mahmoudi et al., 2017; Efstratiou at al., 2017). Interesting is the future study of statistics regarding the measures taken to prevent the disease in children and to treat the sick. However, there is very little information in open sources, which does not allow drawing logical conclusions about the better mitigation of the consequences. 


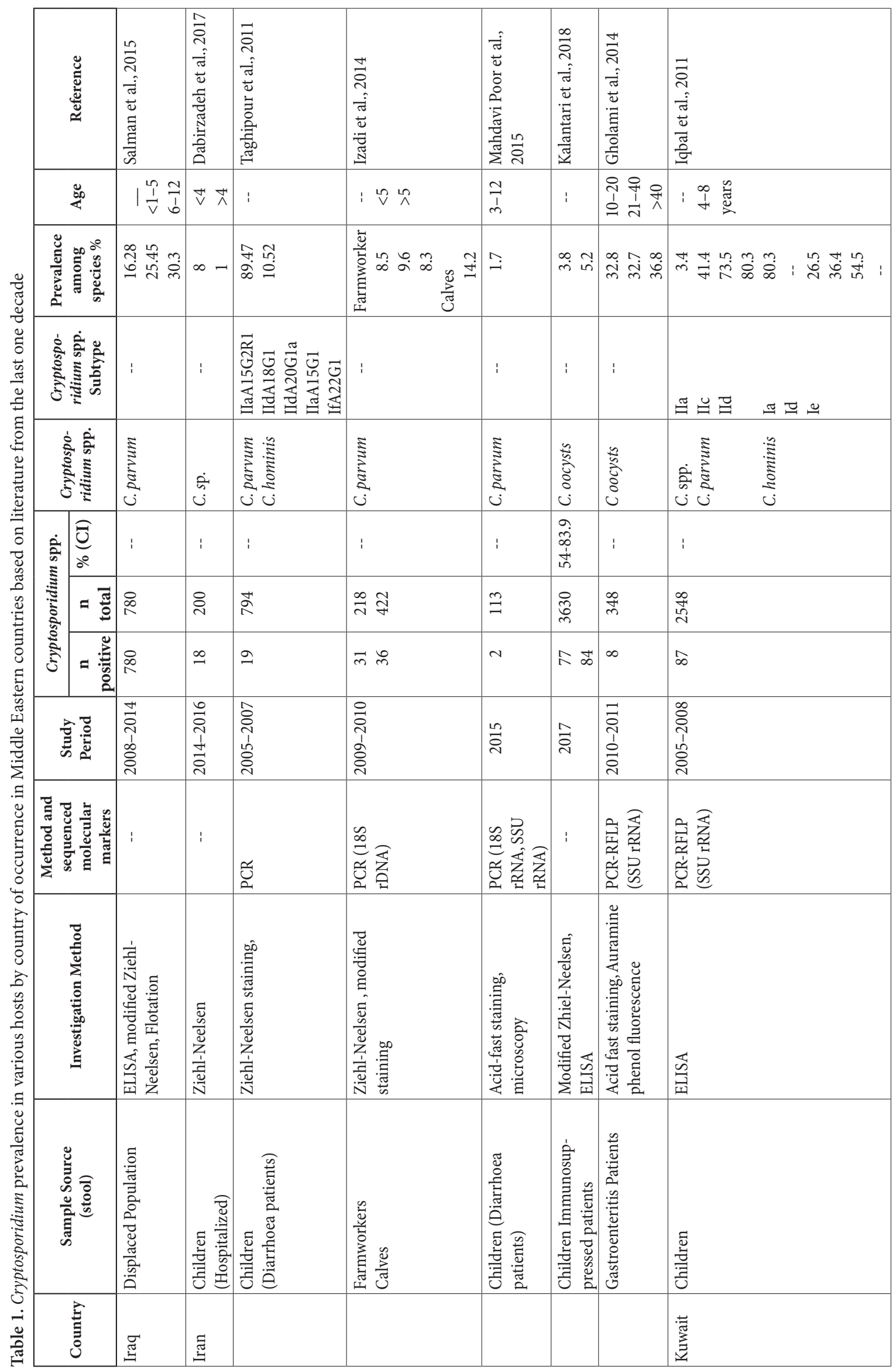




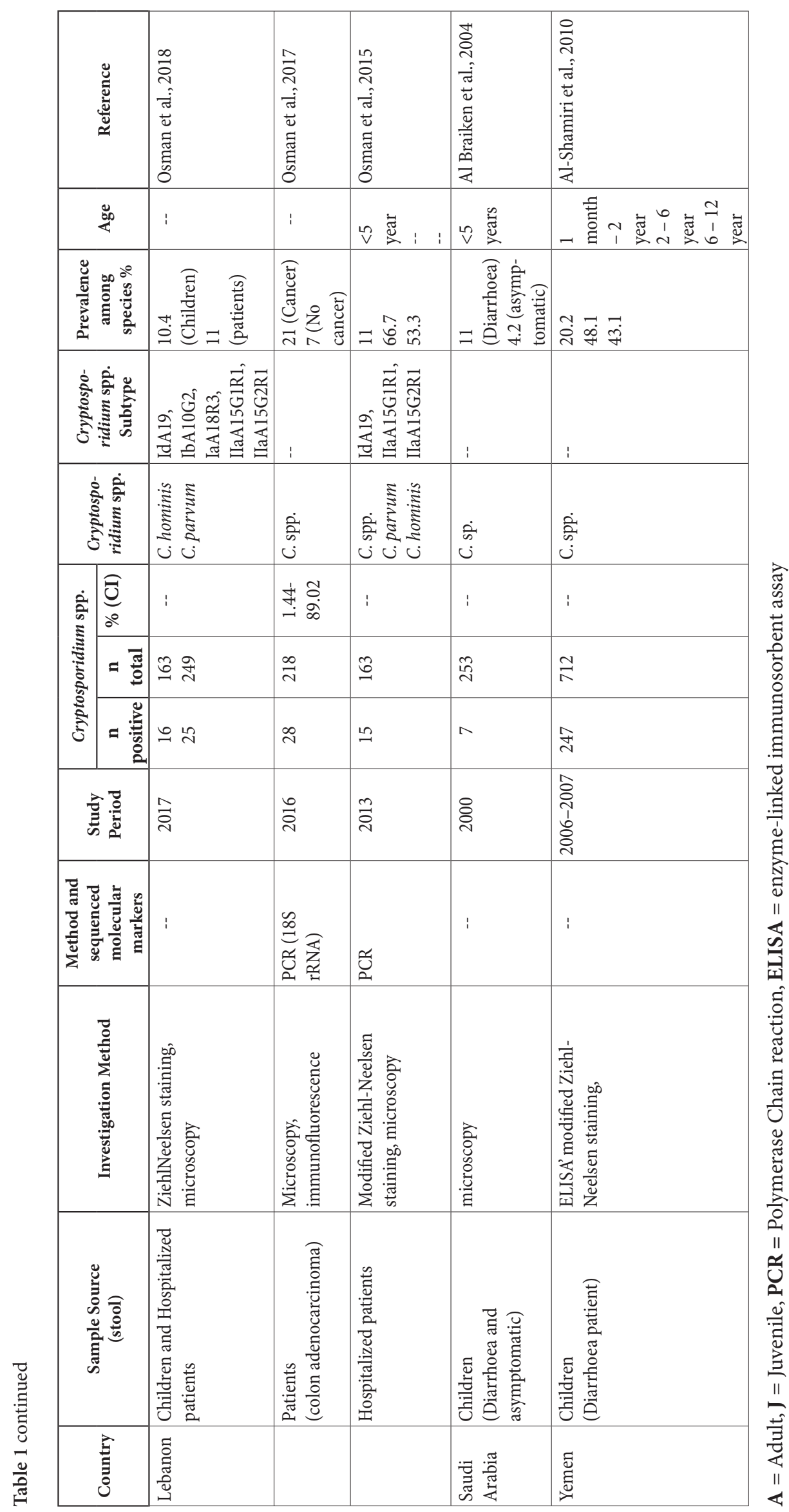


Table 2. Giardia lamblia prevalence in Middle Eastern countries by country of occurrence for the last one decade

\begin{tabular}{|c|c|c|c|c|c|c|c|c|c|c|}
\hline $\begin{array}{c}\text { Coun- } \\
\text { try }\end{array}$ & $\begin{array}{l}\text { Sample } \\
\text { Source }\end{array}$ & $\begin{array}{l}\text { Method } \\
\text { (and } \\
\text { sequence } \\
\text { molecular } \\
\text { markers) } \\
\end{array}$ & $\begin{array}{c}\text { Duration } \\
\text { of study }\end{array}$ & $\begin{array}{c}\mathrm{N} \\
\text { posi- } \\
\text { tive }\end{array}$ & $\mathrm{N}$ total & $\%(\mathrm{CI})$ & Genotype & $\begin{array}{l}\text { Prevalence } \\
\text { among } \\
\text { species }\end{array}$ & Age & Reference \\
\hline \multirow{6}{*}{ Iraq } & $\begin{array}{l}\text { Displaced } \\
\text { Population } \\
\text { (patients) }\end{array}$ & Microscopy & 2014-2015 & 40 & 417 & -- & G. lamblia & 10.31 & -- & $\begin{array}{l}\text { Salman et al., } \\
2016\end{array}$ \\
\hline & $\begin{array}{l}\text { Children } \\
\text { (Diarrhoeal) }\end{array}$ & PCR & 2017 & 108 & 160 & -- & $\begin{array}{l}\text { G. lamblia } \\
\text { Genotype A } \\
\text { Genotype B } \\
\end{array}$ & $\begin{array}{l}26.25 \\
28.57 \\
71.43 \\
\end{array}$ & -- & $\begin{array}{l}\text { Hussein et al., } \\
2018\end{array}$ \\
\hline & \begin{tabular}{|l|} 
Patients \\
(acute or \\
chronic \\
Diarrhoea) \\
\end{tabular} & $\begin{array}{l}\text { Flotation and } \\
\text { PCR }\end{array}$ & 2014-2015 & 73 & 200 & -- & $\begin{array}{l}\text { Genotype A } \\
\text { Genotype B } \\
\text { Genotype E } \\
\text { Genotype F }\end{array}$ & $\begin{array}{l}30.14 \\
26.03 \\
20.55 \\
23.29 \\
\end{array}$ & $>1-40$ & $\begin{array}{l}\text { Turki et al., } \\
2015\end{array}$ \\
\hline & $\begin{array}{l}\text { Children } \\
\text { (Giardia } \\
\text { lambliasis) } \\
\end{array}$ & ELISA & 2016-2017 & 21 & 39 & -- & $\begin{array}{l}\text { Genotype A } \\
\text { Genotype B } \\
\text { Mixed }\end{array}$ & $\begin{array}{r}23.80 \\
71.42 \\
4.76 \\
\end{array}$ & $0-11$ & $\begin{array}{l}\text { Taha et al., } \\
2018\end{array}$ \\
\hline & $\begin{array}{l}\text { Children and } \\
\text { Adults }\end{array}$ & microscopy & 2015-2016 & 31 & 780 & -- & G. lamblia & $\begin{array}{l}3.9 \\
7.3 \\
\end{array}$ & $\begin{array}{l}1-20 \\
>50\end{array}$ & $\begin{array}{l}\text { Bazzaz et al., } \\
2017\end{array}$ \\
\hline & $\begin{array}{l}\text { Children and } \\
\text { Adults }\end{array}$ & microscopy & $2011-2012$ & 97 & 97 & -- & G. lamblia & $\begin{array}{l}25.77 \\
22.68 \\
22.68 \\
\end{array}$ & $\begin{array}{c}1-10 \\
11-20 \\
21-30 \\
\end{array}$ & Khudhair, 2020 \\
\hline \multirow{5}{*}{ Iran } & Humans & microscopy & 2015 & 222 & 4788 & $0.2-2.1$ & G. lamblia & $\begin{array}{l}3.8 \\
9.4 \\
4.9 \\
3.1 \\
3.1 \\
3.3 \\
\end{array}$ & $\begin{array}{c}<5 \\
5-9 \\
10-14 \\
15-24 \\
25-39 \\
>40 \\
\end{array}$ & $\begin{array}{l}\text { Siyadatpanah } \\
\text { et al., } 2018\end{array}$ \\
\hline & $\begin{array}{l}\text { Patients } \\
\text { (Giardia } \\
\text { lambliasis) }\end{array}$ & PCR-RFLP & 2010 & 174 & 205 & -- & $\begin{array}{l}\text { Assemblage AII } \\
\text { Assemblage BII } \\
\text { Assemblage BIV } \\
\text { Mixed A \& B }\end{array}$ & $\begin{array}{r}74.41 \\
17.44 \\
3.49 \\
4.66 \\
\end{array}$ & -- & $\begin{array}{l}\text { Sarkari et al., } \\
2012\end{array}$ \\
\hline & Food Handlers & $\begin{array}{l}\text { Microscopy, } \\
\text { PCR-RFLP }\end{array}$ & 2015 & 47 & 3653 & -- & G. lamblia & 74.5 & -- & $\begin{array}{l}\text { Hooshyar et al., } \\
2017\end{array}$ \\
\hline & Patients & $\begin{array}{l}\text { Microscopy, } \\
\text { PCR (TPI) }\end{array}$ & 2015-2016 & 23 & 1383 & -- & $\begin{array}{l}\text { G. lamblia } \\
\text { Assemblage A } \\
\text { Assemblage B }\end{array}$ & $\begin{array}{l}1.66 \\
52 \\
48 \\
\end{array}$ & -- & $\begin{array}{l}\text { Bahrami et al., } \\
2017\end{array}$ \\
\hline & $\begin{array}{l}\text { Children } \\
\text { (Childcare } \\
\text { centre) }\end{array}$ & Microscopy & 2012 & 134 & 632 & -- & G. lamblia & $\begin{array}{r}13.93 \\
1.74 \\
10.76 \\
14.24 \\
\end{array}$ & $\begin{array}{l}0-6 \\
0-2 \\
2-4 \\
4-6\end{array}$ & $\begin{array}{l}\text { Faraji et al., } \\
2015\end{array}$ \\
\hline Jordan & Patients & PCR (TPI) & 2014-2015 & 49 & 49 & -- & $\begin{array}{l}\text { At tpi locus } \\
\text { A } \\
\text { B } \\
\text { Mixed A \& B } \\
\text { At gdh locus } \\
\text { Assemblage AII } \\
\text { Assemblage B }\end{array}$ & $\begin{array}{l}46.4 \\
50 \\
3.6 \\
\\
43.7 \\
56.3\end{array}$ & $0>-45$ & $\begin{array}{l}\text { Hijjawi et al., } \\
2015\end{array}$ \\
\hline Lebanon & $\begin{array}{l}\text { School } \\
\text { Children }\end{array}$ & \begin{tabular}{|l|} 
Microscopy, \\
Modified \\
Ziehl- \\
Neelsen \\
staining, PCR
\end{tabular} & 2013 & 61 & 212 & -- & G. duodenalis & 28.5 & $3-16$ & $\begin{array}{l}\text { Osman et al., } \\
2016\end{array}$ \\
\hline
\end{tabular}


Table 2 continued

\begin{tabular}{|c|c|c|c|c|c|c|c|c|c|c|}
\hline $\begin{array}{c}\text { Coun- } \\
\text { try }\end{array}$ & $\begin{array}{l}\text { Sample } \\
\text { Source }\end{array}$ & $\begin{array}{l}\text { Method } \\
\text { (and } \\
\text { sequence } \\
\text { molecular } \\
\text { markers) }\end{array}$ & $\begin{array}{c}\text { Duration } \\
\text { of study }\end{array}$ & $\begin{array}{c}\mathrm{N} \\
\text { posi- } \\
\text { tive }\end{array}$ & $\mathbf{N}$ total & $\%(\mathrm{CI})$ & Genotype & $\begin{array}{l}\text { Prevalence } \\
\text { among } \\
\text { species }\end{array}$ & Age & Reference \\
\hline $\begin{array}{l}\text { Saudi } \\
\text { Arabia }\end{array}$ & $\begin{array}{l}\text { General } \\
\text { Population } \\
\text { (Healthcare } \\
\text { facility) }\end{array}$ & PCR-RAPD & 2010 & 15 & 100 & -- & G. duodenalis & 15 & -- & $\begin{array}{l}\text { Shalaby et al., } \\
2011\end{array}$ \\
\hline Syria & Patients & microscopy & 2006 & 206 & 1469 & -- & $\begin{array}{l}\text { Assemblage A } \\
\text { Assemblage B } \\
\text { Mixed A +B }\end{array}$ & $\begin{array}{l}67.5 \\
10 \\
22.5 \\
\end{array}$ & $1-16$ & $\begin{array}{l}\text { Skhal et al., } \\
2016\end{array}$ \\
\hline Yemen & $\begin{array}{l}\text { General } \\
\text { Population } \\
\text { (rural } \\
\text { communities) }\end{array}$ & microscopy & 2012-2014 & 170 & 605 & $\begin{array}{l}0.73- \\
1.48\end{array}$ & G. lamblia & $\begin{array}{l}28.1 \\
33.3 \\
13.5\end{array}$ & $\begin{array}{l}-- \\
<5 \\
>40\end{array}$ & $\begin{array}{l}\text { Al-Mekhlafi et } \\
\text { al., } 2017\end{array}$ \\
\hline
\end{tabular}

\section{Conclusions}

The literature in this study was collected to present an overall scenario of prevalence of Cryptosporidium and Giardia lamblia in Middle Eastern countries. The study is in lieu with literature from other region however in details it varies globally and at local Middle Eastern countries level. The variance of Cryptosporidium and Giardia lamblia follows similar pattern in human and animals as reported worldwide. Poor sanitation and improper hygiene condition are primary responsible for occurrence and thereby transmission of the parasite. However zoonotic transmission arising from animal to human contact is also a significant factor. The most affected section of population comprised of under 5 years of age children, patients (Immune deficient) and weaker economic section of population, moreover, the prevalence among boys was higher than among girls. This is as per the global trend of high prevalence in developing countries than in developed countries.

The major hurdle that the study faced was non uniformity of literature availability. The number of studies varied greatly which impacted the overall study efficiency. For example, Gulf countries viz. Saudi Arabia, Kuwait, Qatar, Bahrain, Oman, United Arab Emirates primarily depend on desalination as drinking water source which limits the need of protozoa occurring research and relevant mitigation measures. In addition, there is heterogeneity in testing procedures and standards across the Middle East, as well as a lack of standardized infrastructure. Hence these countries produced least number of relevant researches works. The other reason for low frequency of published report is the regional instability (political, socio-economical) faced in various countries viz. Syria, Yemen, Iraq, Palestine, Libya and affecting the neighbouring countries thereof (refugees) especially in last one decade which has highly compromised the scope of research in these countries.

Future research work should be based on existing literature on Cryptosporidium and Giardia lamblia. Additionally, future work can be specific to research on molecular techniques which can provide important information on various strains present in Middle Eastern countries. Also, for the future mitigation of the consequences, it is necessary to investigate the appropriate measures that were applied to prevent the disease in children (types of sanitation and hygiene, ways to increase immunity, dietary habits, environment, etc.) and for the treatment of patients (types and schedule of medicinal treatment, restrictions, etc.). The lack of public awareness recognizing Cryptosporidium and Giardia lamblia responsible for Diarrhoea in children needs to be addressed by relevant authorities.

\section{Acknowledgements}

The paper was funded under project scheme, Programme Ibn Khaldoun d'appui à la recherche dans le domaine des Sciences Humaines et Sociales, CNRST, MOROCCO, for Project entitled "Health Security in Casablanca" Project number: IK/2018/23.

\section{References}

Abd El Kader N.M., Blanco M.A., Ali-Tammam M., Abd El Ghaffar A.E.R.B., Osman A., El Sheikh N., Rubio J.M. \& De Fuentes I., 2012, Detection of Cryptosporidium parvum and Cryptosporidium hominis in human patients in Cairo, Egypt. Parasitol. Res. 110: 161-166. https://doi. org/10.1007/s00436-011-2465-6 
Al Braiken F.A., Amin A., Beeching N.J., Hommel M. \& Hart C.A., 2004, Detection of Cryptosporidium amongst diarrhoeic and asymptomatic children in Jeddah, Saudi Arabia. Ann. Trop. Med. Parasitol. 97: 505-510. https:// doi.org/10.1179/000349803235002470

Ali M.A., Khamesipour A., Valian H.K. \& Rahi A.A., 2014, Diarrhea caused by Cryptosporidium parvum in Kut, Iraq using different methods. 2: 1134-1138.

Al-Mekhlafi H.M., 2017, Giardia duodenalis infection among rural communities in Yemen: A communitybased assessment of the prevalence and associated risk factors. Asian Pac. J. Trop. Med. 10: 987-995. https://doi. org/10.1016/j.apjtm.2017.09.011

Al-Shamiri A., Al-Zubairy A. \& Al-Mamari R., 2010, The Prevalence of Cryptosporidium spp. in Children, Taiz District, Yemen., Iran. J. Parasitol. 5: 26-32.

Bahrami F., Zamini G.H., Haghighi A. \& Khademerfan M.B., 2017, Detection and molecular identification of human giardia isolates in the west of Iran. Biomed. Res. 28: 5687-5692.

Bazzaz A.A., Shakir O.M. \& Alabbasy R.H., 2017, Prevalence of two gastrointestinal parasites Entamoeba histolytica and Giardia lamblia within Samarra city, Iraq. Advances in Bioscience and Biotechnology 8(11): 399-410. https:// doi.org/10.4236/abb.2017.811029

Dabirzadeh M., Shahraki M.K., Rostami D. \& Bagheri S., 2017, Prevalence of Cryptosporidium species in children referred to central and hospital laboratories of Zabol City, South East of Iran. Int. J. Pediatr. 5: 6359-6364. https:// doi.org/10.22038/ijp.2017.22358.1871

Dang T.D., Cochrane T.A. \& Arias M.E., 2018, Future hydrological alterations in the Mekong Delta under the impact of water resources development, land subsidence and sea level rise. Journal of Hydrology: Regional Studies. 15: 119-133.

Deineka, D., Kobziev O., Avina S., Grin S., Deyneka V., Taraduda D. \& Sobina V., 2018, Studying the photocatalytic oxidation of hydroxybenzene in aquatic medium on the photocatalizers $\mathrm{SnO} 2, \mathrm{ZnO}, \mathrm{TiO} 2$. Eastern-European Journal of Enterprise Technologies. 5(6/95): 59-67. https://doi.org/10.15587/1729-4061.2018.145198

Efstratiou A., Ongerth J., \& Karanis P., 2017, Evolution of monitoring for Giardia and Cryptosporidium in water. Water Res. 123: 96-112. https://doi.org/10.1016/j. watres.2017.06.042

El-Badry A., Mohammed F. \& Abdul Gawad E., 2018, Predominance of Giardia intestinalis assemblage B in diarrhoeic children in Sharkia, Egypt. Parasitol. United J. 10: 39-43. https://doi.org/10.21608/puj.2017.4735

El Fatni C., Olmo F., El Fatni H., Romero D. \& Rosales M.J., 2014, First genotyping of Giardia duodenalis and prevalence of enteroparasites in children from Tetouan (Morocco). Parasite. 21: 48. https://doi.org/10.1051/parasite /2014049

Faraji R., Ahmadian F., Javadi G. \& Barshahi P., 2015, Prevalence of Giardiasis among children in childcare centers in Kermanshah, Iran. Int. J. Res. Med. Sci. 3: 17171720. https://doi.org/10.18203/2320-6012.ijrms2015025.

Gawad S.S.A., Ismail M.A.M., Imam N.F.A., Eassa A.H.A. \& Abu-Sarea E.Y., 2018, Detection of Cryptosporidium spp. in diarrheic immunocompetent patients in BeniSuef, Egypt: Insight into epidemiology and diagnosis. Korean J. Parasitol. 56: 113-119. https://doi.org/10.3347/ kjp.2018.56.2.113

Ghenghesh K.S., Ghanghish K., BenDarif E.T., Shembesh K. \& Franka E., 2016, Prevalence of Entamoeba histolytica, Giardia lamblia, and Cryptosporidium spp. in Libya: 20002015. Libyan J. Med. 11. https://doi.org/10.3402/ljm. v11.32088

Gholami S., Khanmohammadi M., Ahmadpour E., Paqhe E.S., Nakhjiri S.K., Ramazannipour H. \& Shahbazi A., 2014, Cryptosporidium infection in patients with gastroenteritis in Sari, Iran. Iran. J. Parasitol. 9: 226-232. Ghoneim N.H., Hassanain M.A., Hamza D.A., Shaapan R.M. \& Draz S.H., 2017, Prevalence and Molecular Epidemiology of Cryptosporidium Infection in Calves and Hospitalized Children in Egypt. Res. J. Parasitol. 12: 19-26. https://doi.org/10.3923/jp.2017.19.26

Hijjawi N., Yang R., Mukbel R., Yassin Y., Mharib T. \& Ryan U., 2015, First genetic characterisation of Giardia in human isolates from Jordan. Parasitol. Res. 115: 3723-3729. https://doi.org/10.1007/s00436-016-5132-0

Hooshyar H., Ghafarinasab S., Arbabi M., Delavari M. \& Rasti S., 2017, Genetic variation of Giardia lamblia isolates from food-handlers in Kashan, Central Iran. Iran. J. Parasitol. 12: 83-89.

Hussein A.A., Hussein R.A. \& Shaker M.J., 2018, Enteric viruses co-infection with giardiasis among diarrheal children in Diyala Province-Iraq. J. Pure Appl. Microbiol. 12: 793-799. https://doi.org/10.22207/JPaM.12.2.40

Iqbal J.,Hira P.R.,Al-Ali F. \& Philip R.,2001,Cryptosporidiosis in Kuwaiti children: seasonality and endemicity. Clinical microbiology and infection 7(5): 261-266.

Iqbal J., Khalid N. \& Hira P.R., 2011, Cryptosporidiosis in Kuwaiti children:Association of clinical characteristics with Cryptosporidium species and subtypes. J. Med. Microbiol. 60: 647-652. https://doi.org/10.1099/jmm.0.028001-0

Izadi M., Jonaidi-Jafari N., Saburi A., Eyni H., Rezaiemanesh M.-R. \& Ranjbar R., 2014, Cryptosporidiosis in Iranian Farm Workers and Their Household Members: A Hypothesis about Possible Zoonotic Transmission. J. Trop. Med. 2014: 1-7. https://doi.org/10.1155/ 2014/ 405875 
Kalantari N., Ghaffari S. \& Bayani M., 2018, Cryptosporidium spp.infection in Iranian children and immunosuppressive patients: A systematic review and meta-analysis. Casp. J. Intern. Med. 9: 106-115. https://doi.org/10.22088/ cjim.9.2.106

Khan N.A., Khan S.U., Ahmed S., Farooqi I.H., Hussain A., Vambol S. \& Vambol V., 2019a, Smart ways of hospital wastewater management, regulatory standards and conventional treatment techniques: a short review. Smart and Sustainable Built Environment. DOI: 10.1108/ SASBE-06-2019-0079

Khan N.A., Ahmed S., Vambol S., Vambol V. \& Farooq I.H., 2019b, Field hospital wastewater treatment scenario. Ecological Questions 30(3): 57-69. https://doi. org/10.12775/EQ.2019.022

Khudhair A.A., 2020, Prevalence of Giardia lamblia among Residents of Hawler, Soran and Chamchamal Cities, North of Iraq. Pak-Euro Journal of Medical and Life Sciences 3(2): 28-36.

Liu J., Zhang Q., Singh V.P. \& Shi P., 2017, Contribution of multiple climatic variables and human activities to streamflow changes across China. Journal of Hydrology 545: 145-162.

Mahdavi Poor B., Rashedi J., Asgharzadeh M., Fallah E., Hatam-Nahavandi K. \& Dalimi A., 2015, Molecular Characterization of Cryptosporidium Species in Children with Diarrhea in North West of Iran. Int. J. Mol. Cell. Med. 4: 235-239.

Mahmoudi M.R., Ongerth J.E. \& Karanis P., 2017, Cryptosporidium and Cryptosporidiosis: The Asian perspective. Int. J. Hyg. Environ. Health. 220: 1098-1109. https://doi. org/10.1016/j.ijheh.2017.07.005

Mazzoni A. \& Zaccagni S., 2019, Status of Water Resources and Human Health in the Middle East and North Africa Region: An Integrated Perspective, Reference Module in Earth Systems and Environmental Sciences. Encyclopedia of Environmental Health (Second Edition), pp. 805-817. https://doi.org/10.1016/b978-012-409548-9.11006-1

Michel D., Pandya A., Hasnain S.I., Sticklor R. \& Panuganti S., 2012, Water Challenges and Cooperative Response in the Middle East and North Africa. U.S.-Islamic World Forum, p. 11-15. http://www.brookings.edu/ /media/ Research/Files/Papers/2012/11/iwf papers/Water web. pdf

Osman M., Benamrouz S., Guyot K., Baydoun M., Frealle E., Chabe M., Gantois N., Delaire B., Goffard A., Aoun A., Jurdi N., Dabboussi F., Even G., Slomianny C., Gosset P., Hamze M., Creusy C., Viscogliosi E. \& Certad G., 2017, High association of Cryptosporidium spp. infection with colon adenocarcinoma in Lebanese patients. PLoS One. 12: 1-10. https://doi.org/10.1371/journal.pone.0189422
Osman M., Benamrouz S., Guyot K., El Safadi D., Mallat H., Dabboussi F., Hamze M., Viscogliosi E. \& Certad G., 2018, Molecular epidemiology of Cryptosporidium spp. in North Lebanon. J. Infect. Dev. Ctries. 12: 34S. https://doi. org/10.3855/jidc. 10014

Osman M., El Safadi D., Benamrouz S., Guyot K., Dei-Cas E., Aliouat E.M., Creusy C., Mallat H., Hamze M., Dabboussi F., Viscogliosi E. \& Certad G., 2015, Initial data on the molecular epidemiology of cryptosporidiosis in Lebanon. PLoS One. 10: 6-13. https://doi.org/10.1371/journal. pone.0125129

Osman M., El Safadi D., Cian A., Benamrouz S., Nourrisson C., Poirier P., Pereira B., Razakandrainibe R., Pinon A., Lambert C., Wawrzyniak I., Dabboussi F., Delbac F., Favennec L., Hamze M., Viscogliosi E. \& Certad G., 2016, Prevalence and Risk Factors for Intestinal Protozoan Infections with Cryptosporidium, Giardia, Blastocystis and Dientamoeba among Schoolchildren in Tripoli, Lebanon. PLoS Negl. Trop. Dis. 10. https://doi.org/10.1371/journal. pntd.0004496

Salman Y.J., Aziz Al-Taee A.-R. \& Abid A.M., 2016, Prevalence of Giardia lamblia among Iraqi Displaced Peoples in Kirkuk Province. Int. J. Curr. Microbiol. Appl. Sci. 5: 753-760. https://doi.org/10.20546/ijcmas.2016.501.076

Salman Y.J., Sadek W.S. \& Rasheed Z.K., 2015, Original Research Article Prevalence of Cryptosporidium parvum among Iraqi displaced people in Kirkuk city using direct microscopy. Flotation technique and ELISA-copro antigen test 4: 559-572.

Sarkari B., Ashrafmansori A., Hatam G.R., Motazedian M.H., Asgari Q. \& Mohammadpour I., 2012, Genotyping of Giardia lamblia isolates from human in southern Iran. Trop Biomed. 29(3): 366-71.

Shalaby I., Gherbawy Y. \& Banaja A., 2011, Molecular characterization of Giardia parasite isolated from stool samples collected from different hospitals in Taif City (Saudi Arabia). Trop Biomed. 28(3): 487-496.

Shalaby N.M. \& Shalaby N.M., 2015, Cryptosporidium parvum Infection among Egyptian School Children. J. Egypt. Soc. Parasitol.45: 125-131.https://doi.org/10.12816/0010858 Siyadatpanah A., Sharif M., Daryani A., Sarvi S., Kohansal M.H., Barzegari S., Pagheh A.S. \& Gholami S., 2018, Spatial distribution of Giardia lamblia infection among general population in Mazandaran Province, north of Iran. J. Parasit. Dis. 42: 171-176. https://doi.org/10.1007/ s12639-018-0976-0

Skhal D., Aboualchamat G. \& Al Nahhas S., 2016, Giardia duodenalis in Damascus, Syria: Identification of Giardia genotypes in a sample of human fecal isolates using polymerase chain reaction and restriction fragment length polymorphism analyzing method. Acta Trop. 154: 1-5. https://doi.org/10.1016/j.actatropica.2015.10.008 
Taghipour N., Nazemalhosseini-Mojarad E., Haghighi A., Rostami-Nejad M., Romani S., Keshavarz A., Alebouyeh M. \& Zali M.R., 2011, Molecular epidemiology of cryptosporidiosis in Iranian children, Tehran, Iran. Iran. J. Parasitol. 6: 41-45.

Taha S.A., Zein Abd Al Aal, Saleh N.S., \& El-Badry A.A., 2018, Giardia intestinalis assemblages among Egyptian symptomatic children: Prevalence and seasonal distribution in Cairo, Egypt. Journal of the Egyptian Society of Parasitology 48(3): 661-668.

Terink W., Immerzeel W.W. \& Droogers P., 2013, Climate change projections of precipitation and reference evapotranspiration for the Middle East and Northern Africa until 2050. Int. J. Climatol. 33: 3055-3072. https:// doi.org/10.1002/joc.3650

Turki N.M., Mallah M.O. \& Kremsh Y.D., 2015, Iraqi Genotyping of Giardia lambila (A, B, E, F) in Human Stool In AL-Muthanna Province-Iraq. International Journal 3(10): 757-771.
U.S.H.O.F., 2016, Representatives: I. Raad, G.P. Bodey, E. Health, The growing threat of cholera and other diseases in the middle east committee on foreign affairs subcommittee on Africa, global health. U.S. House of Representatives Health Outreach to the Middle East, President.

WHO, 2019, Cholera Situation in Yemen, 22765604. http:// www.emro.who.int/images/stories/csr/documents/ Cholera_situation_update_Yemen_February_2019. pdf?ua $=1$

Xu H. \& May M.W., 2017, Water Availability Indices A Literature Review. Argonne Natl. Lab. https://doi. org/10.2172/1348938

Ziarati P., Kozub P., Vambol S., Vambol V., Khan N.A., Kozub S. \& Tajik S., 2021, Kinetics of Cd, Co and Ni Adsorption from Wastewater using Red and Black Tea Leaf Blend as a Bio-adsorbent. Ecological Questions 32(2): 1-20. http:// dx.doi.org/10.12775/31823 